\title{
Production Potential and Quality of Chenopodium quinoa Willd. Seed Cultivated in Different Seeding Seasons
}

\author{
D. B. Rodrigues ${ }^{1}$, L. V. M. Tunes ${ }^{1}$, F. A. Villela ${ }^{1}$, G. I. Gadotti ${ }^{1}$, C. J. Costa ${ }^{2}$, T. D. Rosa ${ }^{1}$, \\ D. Medeiros ${ }^{1}$, J. A. Gularte ${ }^{1}$, E. Gewehr ${ }^{1}$, A. S. Almeida ${ }^{1} \&$ C. Nunes ${ }^{1}$ \\ ${ }^{1}$ Faculdade de Agronomia Eliseu Maciel, Universidade Federal de Pelotas, Capão do Leão, Brazil \\ ${ }^{2}$ Embrapa Clima Temperado, Pelotas, Brazil \\ Correspondence: D. B. Rodrigues, Faculdade de Agronomia Eliseu Maciel, Universidade Federal de Pelotas, Av. \\ Eliseu Maciel s/n, Capão do Leão, Brazil. Tel: 55-5332-757-462. E-mail: ufpelbrandstetter@hotmail.com
}

Received: August 17, 2018

Accepted: October 16, 2018

Online Published: December 15, 2018

doi:10.5539/jas.v11n1p251

URL: https://doi.org/10.5539/jas.v11n1p251

\begin{abstract}
Quinoa (Chenopodium quinoa Willd.) is an annual plant belonging to subfamily Chenopodiaceae containing such granite importance, being considered a pseudocereal. For the quinoa to gain widespread attention, to the point of achieving large scale cultivation in Brazil it is necessary for the studies to advance specially in regards to quality of produced seeds. The main aim of this work was to evaluate potential of quinoa seed's production cultivated in different seasons, as well as quality of seeds produced on primary and secondary stalks of quinoa plants from BRS Piabiru, produced in the South of Rio Grande do Sul (RS), Brazil. The evaluated seeding seasons were October, November and December, June, July and August of the years 2015/2016, after the plants were taken to evaluation regarding agronomical characters (fresh mass of ramification glomeruli, main glomeruli, fresh mass of stem from the main, fresh mass of stem ramification, fresh mass of leaves, dry mass of stem ramification, stem from the main, glomeruli from the main, stem ramification, of leaves, diameter of stem and panicle lenght) and quality of seeds (germination, test of cold, accelerated aging, and seed's emergency). Quality of the seed is assured when it's produced after months of July, August and November, given that quality of seeds from main stem is superior.
\end{abstract}

Keywords: quinoa, pseudocereal, strenght, germination, BRS Piabiru

\section{Introduction}

Quinoa (Chenopodium quinoa Willd.) is an annual plant belonging to Chenopodiaceae subfamily containing great granite importance, being considered a pseudocereal or pseudo-oleaginous (Leòn \& Rosell, 2007). Native from Andes Mountain Range (Spehar \& Santos, 2002), nowadays it's cultivated mainly in Bolivia, Peru, USA, Equator, some areas of Colombia, Chile, Argentina (León \& Rosell, 2007) and South America (Madl et al., 2006).

According to Walters et al. (2016), quinoa's grain is rich in proteins and contains a balanced profile of amino acids compared to regular cereal grains. It does not contain gluten in its composition, besides it contains all of the amino acids essential to human being, such as lysine, isoleucine, leucine, phenylalanine, tyrosine, threonine, tryptophan, valine, histidine and methionine.

In Brazil the specie has just recently begun to being studied and cultivaved (about the 90s), mostly concentrating in Brazil's central region. According to studies made on quinoa in the state of Paraná, cultivation can be an alternative to substitute the region's agriculture during smaller crops, in those periods in which rain levels are lower, and average temperature is also cooler than those during the Summer (Cardoso et al., 2004).

For the quinoa to be widespread, so that it achieves large scale cultivation it is necessary that studies focus on the adequate management in relation to local environmental conditions. For it is a species that suffers great environmental influence over its performance, mainly due to rain and temperature (Rocha, 2008).

Performance components, cycle's duration, as well as productivity are of the utmost importance for cultivation sucess and those are strongly influenced by handling. Nevertheless, no cultural practice is more important than seeding season (Peixoto et al., 2000; Pelúzio et al., 2006).

Seeding season encompasses a set of environmental factors that react among themselves and interact with the plant, causing production variations and thus on quality of produced seeds. Cultivated in different seasons, the act of 
cultivating expresses its potentiality in relation to environmental conditions, that vary in space (altitude and latitude) and time (year's period) (Sphear, Santos, \& Veloso, 2007).

Species repond differently to environment and the indications of best time for each one of them must be preceded by regional rehearsals. Although the only available way to cultivate quinoa in the Market (BRS Piabiru) in Brazil reccomended to general weather and environmental conditions is known according to exposure to indispensability of specific informations to the intended cultivation region (Sphear, Santos, \& Veloso, 2007). Regarding seeding time upon seed's quality it is known that this is an issue that encompasses several weather factors, that interfere within formation and deterioration of produced seeds. Abiotic factors ocurred during physiological maturity, for example, promote reduction of seed's dry mass, weight of 1.000 seeds, strenght, viability e visual quality (Peske; Villela, \& Meneghello, 2012).

Seed's deterioration occurs during and mainly after physiological maturation, period in which plants are in development and growing in the field (Sphear, Santos, \& Veloso, 2007). According to this situation knowledge is necessary regarding quality of the seeds produced in primary and secondary stems in order to plan harvest predicting production of high quality seeds.

So with this work the goal was to evaluate production of quinoa (Chenopodium quinoa Willd.) seeds potential cultivated in diferent seasons, as well as quality of seeds produced in primary and secondary stems from quinoa plants on cultivate BRS Piabiru, produced in the South of Rio Grande do Sul (RS), Brazil.

\section{Material and Methods}

Experiment was conducted in the Host Station of Research of Embrapa Temperate Climate in Pelotas during 2015/2016 harvest and agricultural year 2016, Rio Grande do Sul, Brazil, latitude 31 $40^{\prime} 53.6^{\prime \prime}$ S, longitude $52^{\circ} 26^{\prime} 23.5^{\prime \prime} \mathrm{W}$ altitude of 67.10 meters. The quinoa cultivating utilized was BRS Piabiru.

Climate's classification in the region, according to Köppen, is of the Cfa kind, which means, humid subtropical with no definite dry season containing hot summers (Wrege et al., 2011). Soil is classified as Solodic Eutrophic Hexic Plane Soil (Streck et al., 2008). It was utilized experimental lineation in random complete blocks, with four repetitions.

Seeding seasons (October, November and December, June, July and August 2015/2016), had an interval of one seeding to another in a period of 30 days. For such two experiments were performed in separate, which means, one during three months in the hottest period (October, November and December/2015) and another during the coldest period (June, July and August/2016). Each plot had $3 \times 2 \mathrm{~m}$, and spacing between lines was $0.30 \mathrm{~m}$, keeping 12 plants $\mathrm{m}$ linear. Seeding was performed manually, in lines, at a depht of $3 \mathrm{~cm}$. It was necessary to do weed control, performed by periodic manual weeding.

Metereological variables such as air temperature and montly rain and solar radiation (Figures 1, 2, 3 and 4) were obtained through Agroclimatological Station of Pelotas (Latitude: $31^{\circ} 52^{\prime} 00^{\prime \prime}$ S, Longitude: 52 $21^{\prime} 24^{\prime \prime} \mathrm{W}$, Altitude: $13.24 \mathrm{~m}$ ), operated through an agreement between Embrapa Temperate Climate, the Federal University of Pelotas and the National Institute of Meteorology.

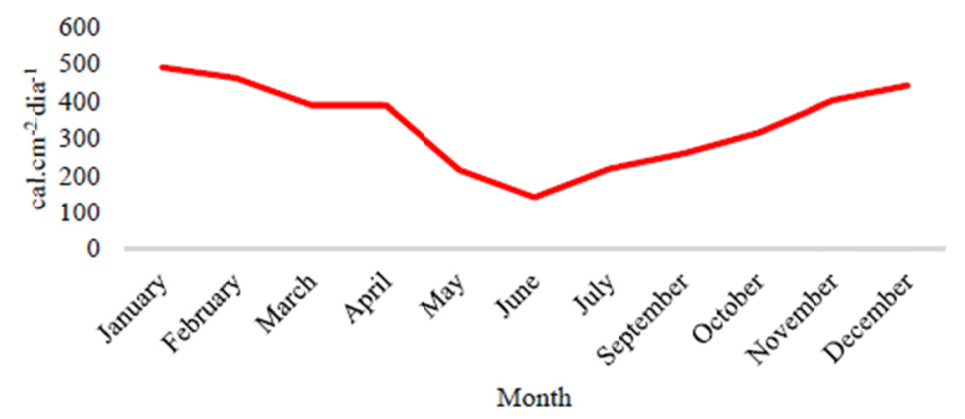

Figure 1. Average values of solar radiation from the year of 2015, of each month

Source: Agroclimatological Station of Capão do Leão, RS. 


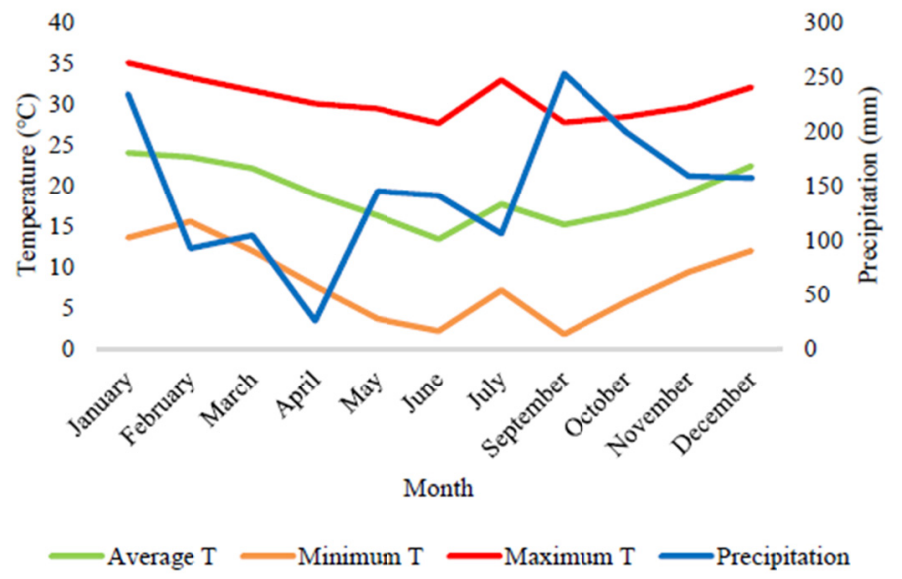

Figure 2. Climatic scenario of 2015, including averages of minimum, medium and maximum air temperature from each month

Source: Agroclimatological Station of Capão do Leão, RS.

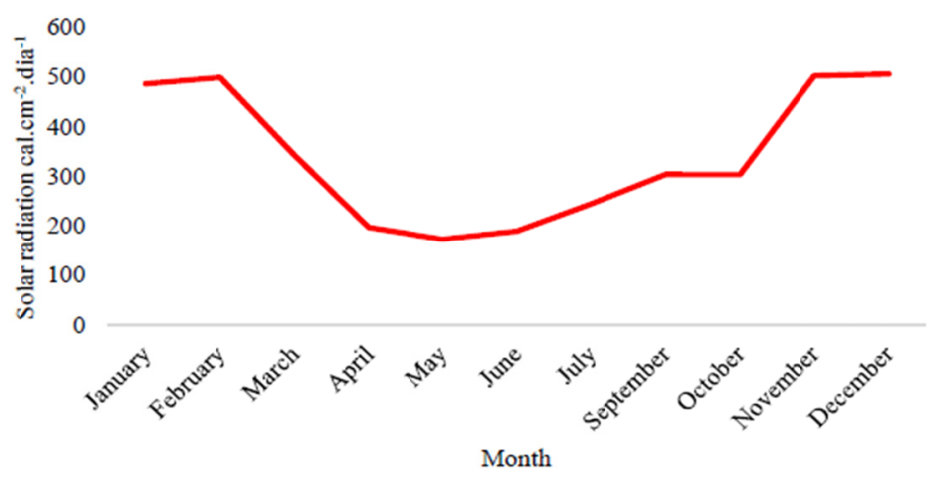

Figure 3. Average values of solar radiation from the year of 2016, of each month

Source: Agroclimatological Station of Capão do Leão, RS.

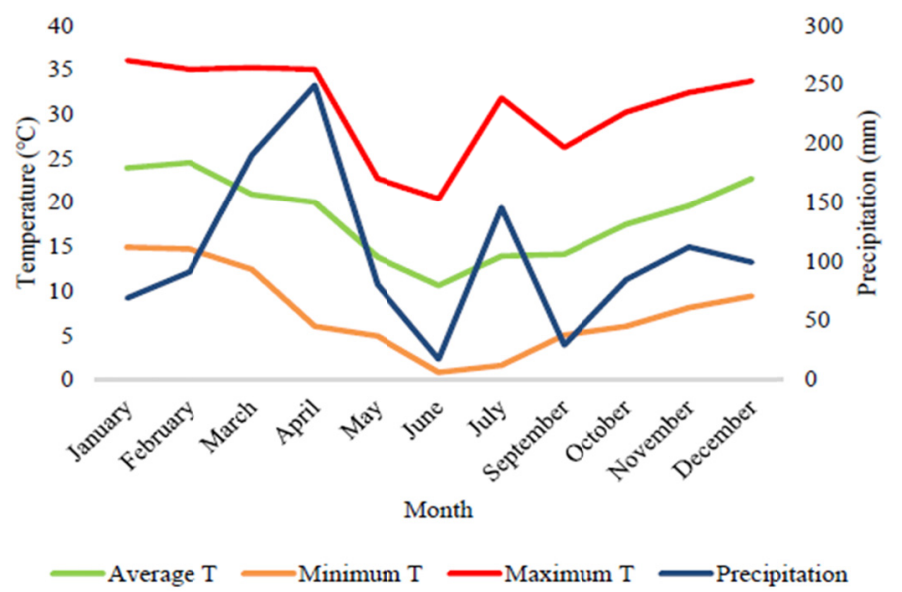

Figure 4. Climatic scenario of 2016, including averages of minimum, medium and maximum air temperature from each month

Source: Agroclimatological Station of Capão do Leão, RS.

As for seed's maturation it is known that it is usually followed by visible changes in its external aspect and fruits and seeds coloration according to Carrasco (2003), thus this evaluation was continuosly made by visual analysis 
during the plants development. Plants were harvested in the moment in which it was verified a greater quantity of panicle seeds were being exposed beyond the perigones (structures which cover the seeds).

After plants were taken to evaluation regarding their agronomical characters (fresh mass of ramification glomeruli, fresh mass of main glomeruli, fresh mass of stem from the main, fresh mass of ramification stem, fresh mass of leaves', dry mass of ramification stem, dry mass of stem from the main, dry mass of glomeruli from the main, dry mass of ramification stem, dry mass of leaves', diameter of stem (basal, diameter of stem), diameter of stem-apex, plant height, panicle lenght and quality of seeds (germination, test of cold, accelerated aging, seeds emergency-main and ramification).

Collected material, after measurements according to plot's identification, was dry in an oven of forced air renewal/circulation to the temperature of $65^{\circ} \mathrm{C}$, until achieving a constant mass. After achieving a constant mass, the material was properly weighted, obtaining dry matter's total weight, next the seeds were pinched (by the set of strainers "Granutest ${ }^{\mathbb{B}}$ ") getting rid of any specks.

Regarding physiological quality of the seeds the following analysis were made:

Germination (G): it was performed with four repetition of 50 seeds, being applied two sheets of blotting paper, moisted on distilled water in the quantity of 2.5 times dry paper's mass; germinator on which seeds were displayed was adjusted to $20^{\circ} \mathrm{C}$ and evaluations were made on the 4th and 6th day after seeding (Borges, 2017).

Accelerated aging (EA): it were utilized boxes of "gerbox" kind as individual container (mini chamber), having in its interior a tray with aluminium grille $(0.5 \mathrm{mg})$ were distributed in a uniform layer. Inside each individual compartment were added $40 \mathrm{~mL}$ of solution (11 $\mathrm{g}$ of NaCl$/ 100 \mathrm{~mL}$ of water); boxes were kept in chambers of the BOD kind, at $41{ }^{\circ} \mathrm{C}$ for $72 \mathrm{~h}$. Then, seed were submitted to germination test, being evaluated after four days and results were expressed in percentage of normal seedling (Borges, 2017).

Test of cold (TF): conducted with four repetitions of 50 seeds, evenly distributed on two sheets of blotting paper inside plastic boxes of gerbox kind, moistered with distilled water in the proportion of 2.5 times dry paper mass. Soon after, boxes were taken to BOD in the temperatures of $2{ }^{\circ} \mathrm{C}$ for a period of 5 days. Then, seeds were transfered to germinator, at $20^{\circ} \mathrm{C}$, for four days, and next countings of normal seedlings were made. Results were expressed in percentage of normal seedlings (Borges, 2017).

Emergency (E): it was performed utilizing four sub-samples of 100 seeds, sown in plats of $5.0 \times 1.2 \times 0.9 \mathrm{~m}$ filled with soil collected from horizon A1 of a solodic eutrophic hexic Plane Soil. Seeding was equidistant and in the depht of $0.03 \mathrm{~m} .14$ days after seeding the number of emerged seedling was counted and results were expressed in percentage.

For the making to the tests it was applied an experimental lineation completely random, with four repetitions, data concerning measured variables will be submitted to variance level.

Data obtained were submitted to variance analysis with the help of a statistical software RStudio (Verzani, 2008). Fresh mass leaf data have suffered square root transformation $\sqrt{(\mathrm{x}+\mathrm{k})}$ in which $\mathrm{k}=0.5$, and fresh mass data from ramification stem, fresh mass of leaves, fresh mass of ramification glomeruli, fresh mass of glomeruli from the main, fresh mass of main stem, fresh mass of ramification stem, fresh mass of ramification glomeruli and lenght of panicle of the second experiment (seeding during months of June, July and August) have suffered logarithmic transformation (of base 10) $\log \mathrm{x}$.

\section{Results and Discussion}

There was a significant difference regarding seeding season (November, December and January of 2015/2016) of quinoa over fresh mass of ramification glomeruli, fresh mass of glomeruli from the main, fresh mass of stem from the main, fresh mass of ramification stem, and fress mass of leaves (Table 1). 
Table 1. Average fresh mass values ( $\mathrm{g}$ ) of the ramification glomeruli (MFGR), fresh mass of glomeruli from the main (MFGP), fresh mass of stem from the main (MFCP), fresh mass of ramification stem (MSCR), and fresh mass from the leaves (MFF), from quinoa cultivation during three seeding seasons, in Pelotas, RS, 2015/2016

\begin{tabular}{llllll}
\hline & MFGR $(\mathrm{g})$ & MFGP $(\mathrm{g})$ & MFCP $(\mathrm{g})$ & MFCR $(\mathrm{g})$ & MFF $(\mathrm{g})$ \\
\hline November & $97.88 \mathrm{a}$ & $40.81 \mathrm{a}$ & $101.41 \mathrm{a}$ & $42.04 \mathrm{a}$ & $40.49 \mathrm{a}$ \\
December & $44.61 \mathrm{~b}$ & $34.09 \mathrm{a}$ & $52.96 \mathrm{~b}$ & $44.61 \mathrm{a}$ & $43.69 \mathrm{a}$ \\
January & $8.64 \mathrm{c}$ & $13.39 \mathrm{~b}$ & $49.96 \mathrm{~b}$ & $5.71 \mathrm{~b}$ & $5.16 \mathrm{~b}$ \\
Average & 50.38 & 29.43 & 68.11 & 30.79 & 29.78 \\
CV $(\%)$ & 20.95 & 38.23 & 38.18 & 22.67 & 27.56 \\
\hline
\end{tabular}

Note. *Average followed by same letter in the column, do not differ statistically among themselves by the Tukey test $(\mathrm{p}<0.05)$.

The verified influence of seeding season over such variables can be justified by the fact that this species is classified as a short-days plant, suffering alterations according to solar radiation (Figure 1) present during the peridod of this species development and growing in the fields (Carbone-Risi, 1986).

Only production installed during the month of November has shown significantly greater values (on all of Table 1 variables), and also the month of January has drastically differed in terms of statistics presenting a negative influence on all of the variables (Table 1). This could indicate that the combination of high temperatures and relatively low levels of rain, specially in the begining of development (stablishment) of quinoa, may have negatively interfered on this species development as a plant.

On Table 2 it is observed that are the same variables forementioned, although as for the dry mass value they've kept their behaviour in relation to seeding season, which is, January has performed a value statistically lower than November and December, only the leaves dry mass the month of December has performed a value that was statistically similar. It is worth mentioning that the leaves dry mass reveals much about the decision-making of which season is adequate for seeding when the goal is seeds' productioon, since leaves are the main sources of sugar produced in photossynthesis that by itself will influence on quality and productivity of resulting seeds (Marcos Filho, 2015).

Table 2. Average dry mass values (g) of ramification glomeruli (MSGR), dry mass of glomeruli from the main (MSGP), dry mass of stem from the main (MSCP), dry mass of ramification stem (MSCR), and dry mass of leaves (MSF), from quinoa cultivation, during three seeding seasons, in Pelotas, RS

\begin{tabular}{llllll}
\hline & MSGR $(\mathrm{g})$ & MSGP $(\mathrm{g})$ & MSCP $(\mathrm{g})$ & MSCR $(\mathrm{g})$ & $\mathrm{MSF}(\mathrm{g})$ \\
\hline November & $23.57 \mathrm{a}^{*}$ & $18.12 \mathrm{a}$ & $44.63 \mathrm{a}$ & $29.21 \mathrm{a}$ & $7.37 \mathrm{a}$ \\
December & $13.57 \mathrm{a}$ & $14.22 \mathrm{a}$ & $32.96 \mathrm{a}$ & $22.73 \mathrm{a}$ & $2.69 \mathrm{~b}$ \\
January & $2.34 \mathrm{~b}$ & $4.15 \mathrm{~b}$ & $12.77 \mathrm{~b}$ & $1.35 \mathrm{~b}$ & $1.05 \mathrm{~b}$ \\
Average & 13.16 & 12.16 & 30.12 & 17.76 & 3.70 \\
CV $(\%)$ & 33.18 & 24.82 & 10,9 & 52.92 & 29.57 \\
\hline
\end{tabular}

Note. * Average followed by same letter in the column, do not differ statistically among themselves by Tukey test ( $\mathrm{p}$ $<0.05)$.

Seeding performed during the months of December and January have statistically differed from November's month as for its dry mass from leaves (Table 2). That said, one can claim that those months should not be reccomended for seeding of the species, since this variable has presented itself as inferior and the importance of this value is crucial for the production of photoassimilates, those which will be carried to seeds in formation (Peske, Villela, \& Meneghello, 2012).

On Table 3 are presented data analysed regarding agronomical characters. It was evaluated stem diameter (basal area, average and apex of the plants) where only data relative to diameter of basal area have shown significant differences as for seeding times. The month of November and January have demonstrated a negative influence, which means, lower values. It is necessary to emphasize that grains/seeds performance vary according to genotype and variables such as stem diameter, plant height, panicle size, among others (Rojas \& Pinto, 2013). 
Table 3. Diameter of stem-basal (DBC), diameter of stem-mediated (DCM), diameter of stem-apex (DCA), Height of planta (AP), and panicle Length (CP) produced during three seeding seasons. Pelotas, RS, 2015/2016

\begin{tabular}{llllll}
\hline & DCB $(\mathrm{cm})$ & DCM $(\mathrm{cm})$ & DCA $(\mathrm{cm})$ & AP $(\mathrm{cm})$ & CP $(\mathrm{cm})$ \\
\hline November & $1.1 \mathrm{ab} *$ & 0.8 & 0.6 & $116.4 \mathrm{~b}$ & $36.3 \mathrm{a}$ \\
December & $1.1 \mathrm{a}$ & 0.8 & 0.5 & $153.9 \mathrm{a}$ & $32.0 \mathrm{a}$ \\
January & $0.8 \mathrm{~b}$ & 0.6 & 0.4 & $114.0 \mathrm{~b}$ & $20.1 \mathrm{~b}$ \\
Average & 1.0 & $0.73^{\text {ns }}$ & $0.5^{\text {ns }}$ & 128.1 & 29.47 \\
CV $(\%)$ & 26.98 & 35.44 & 33.99 & 16.26 & 4.17 \\
\hline
\end{tabular}

Note. *. Average followed by same letter in the column, do not differ statistically among themselves by Tukey test ( $p$ $<0.05) .{ }^{\text {ns }}$ Non significant by the test $F$.

Some claim that quinoa plants can reach until two meters of height, altough in the work done by Soares de Vasconcelos et al. (2012), with the same seeding utilized in this present work, but in the central area of Brazil, the average found value was of $65 \mathrm{~cm}$, lower than plants produced here in the southern region of Rio Grande do Sul, which measured between 114.0 to $153.9 \mathrm{~cm}$ (Table 3). The present authors claim that those results relative to the plants' height show the relation between temperature during vegetative state and their development.

Panicle lenght, in general has fitted within range of already found values (15 to $70 \mathrm{~cm}$ ) by Hunziker (1943). In this research the highest values were of $36.3 \mathrm{~cm}$ during December's seeding, followed by November, with $32.0 \mathrm{~cm}$.

In general, seeds coming from tested seeding seasons had a good development, allowing the making of a physiological evaluation of the seeds a posteriori. For such, it were made germination tests, tests of cold, accelerated aging and emergency (Table 4).

Table 4. Percentage of germination (G), test of cold (TF), accelerated aging (EA), and emergency (E) of seeds (main stem and ramifications) produced during three months of seeding (November, December and January). Pelotas, RS, 2015/2016

\begin{tabular}{|c|c|c|c|c|c|}
\hline \multirow{2}{*}{ Variable } & \multirow{2}{*}{ Location on plant } & \multicolumn{3}{|c|}{ Season } & \multirow{2}{*}{ Average } \\
\hline & & November & December & January & \\
\hline \multirow[t]{4}{*}{ G (\%) } & Main & $80 *$ & 87 & 81 & $82 a$ \\
\hline & Ramification & 63 & 75 & 70 & $69 b$ \\
\hline & Average & $71^{\mathrm{ns}}$ & $81^{\mathrm{ns}}$ & $76^{\mathrm{ns}}$ & \\
\hline & $\mathrm{CV}(\%)$ & 10.68 & & & \\
\hline \multirow[t]{4}{*}{$\mathrm{TF}(\%)$} & Main & $86 \mathrm{aA}$ & $96 \mathrm{aA}$ & $91 \mathrm{aA}$ & 91 \\
\hline & Ramification & $65 \mathrm{bB}$ & $95 \mathrm{aA}$ & $93 \mathrm{aA}$ & 84 \\
\hline & Average & 75 & 95 & 92 & \\
\hline & CV $(\%)$ & 6.47 & & & \\
\hline \multirow[t]{4}{*}{ EA $(\%)$} & Main & $95 \mathrm{aA}$ & $98 \mathrm{aA}$ & $98 \mathrm{aA}$ & 97 \\
\hline & Ramification & $100 \mathrm{aA}$ & $96 a A$ & $72 \mathrm{bB}$ & 89 \\
\hline & Average & 97 & 97 & 85 & 93 \\
\hline & $\mathrm{CV}(\%)$ & 5.1 & & & \\
\hline \multirow[t]{4}{*}{$\mathrm{E}(\%)$} & Main & $92.5 \mathrm{aA}$ & $100 \mathrm{aA}$ & $70 \mathrm{aB}$ & 88 \\
\hline & Ramification & $55 \mathrm{bB}$ & $65 \mathrm{bAB}$ & $80 \mathrm{aA}$ & 67 \\
\hline & Average & 74 & 83 & 75 & \\
\hline & $\mathrm{CV}(\%)$ & 13.93 & & & \\
\hline
\end{tabular}

Note. *Average followed by same letter in the column, do not differ statistically among themselves by Tukey test ( $\mathrm{p}$ $<0.05) .{ }^{\text {ns }}$ Non significant by the test $\mathrm{F}$.

Regarding seeds viability coming from the main stem, it was concluded that result was satisfactory, which means, seeds attend to minimum legal requirements for them to be commercialized (minimum of 80\%). The same has not happened with the seeds resulting from plant ramification, because values have performed only between 63 and $75 \%$ of germination (Table 4 ).

Quinoa plants present high capacity of ramification, while in conditions of growing in low populational densities. However, maturation process of the quinoa seeds is quite heterogeneous between panicles of primary and secondary 
stes and within same inflorescence (Spehar, Santos, \& Veloso, 2007). Because of that it is of major importance the knowledge about quality of produced seeds in the primary and secondary stems (ramifications) in order to manage harvesting aiming production of high quality seeds. During this experiment no meaningful differences were checked regarding germination potential between seeding seasons, only between main stem and ramifications.

Regarding evaluation of produced seeds' strenght (tests of cold, accelerated aging and emergency) it is observed yet on Table 4 that there was interaction between seeds produced during different seasons and plants' location (main stem and ramifications).

Test of cold has differed as for strenght only for those seeds coming from ramifications of November's seeding season (that one presenting a statistically lower value). However, due to quinoa being originally from low temperature regions, tolerating temperatures of $-4{ }^{\circ} \mathrm{C}$, so that the evaluation test of quinoa seeds' strenght utiliing low temperatures might not be the most adequate since even on $2^{\circ} \mathrm{C}$, germination happens as it should (FAO, 2011).

Among the available tests accelerated aging is one of the most susceptible and efficient to evaluation of different species strenght (Marcos Filho, 2015). In this experiment the forementioned test has shown that seeds produced during the three seasons and two evaluated places possess high strenght value, but has differed only on the ramification seeds after seeding during the month of January.

Emergency values corroborate with strenght data from tests of cold regarding seeds from main stem from different seasons while in comparison to those of ramification, however value regarding produced seeds from ramification during the month of December are of lower quality if compared to the months of November and January.

The emergency test is an important evaluation for obtaining knowledge of strenght, because although it takes longer it presents a better picture of real seeding conditions. If properly executed, it will provide the lot's capacity to stablish itself, providing necessary subsidies for the calculation of seeds' number to be utilized in order to obtain a desirable population or plant stand (Nakagawa, 1994).

At a second moment, it was performed another experiment with the same experimetal lineation and also with same evaluations, although during different seasons (months of June, July and August). This initiative was carried in order to evaluate production/quality of seeds during winter months in Rio Grande do Sul, since this is a period in which cultivation is poorly explored, because of weather limitations. As one can see in the figures 2 and 3 those are months of extremely low temperatures and also lower solar radiation.

In the evaluation of fresh mass ramification glomeruli, fresh mass of glomeruli from the main and fresh mass of ramification stem there was no meaningful difference as for seeding months. However, if we observe on Table 5 values of fresh mass from the main stem the month of July has presented significantly lower vales. On the other hand, as for values of fress mass from the leaves, it is observed that the month of June has presented a statistically higher value.

Table 5. Average values of fresh mass (g) of ramification glomeruli (MFGR), fresh mass of glomeruli from the main (MFGP), fresh mass of stem from the main (MFCP), fresh mass of ramification stem (MSCR), and fresh mass of leaves (MFF), from quinoa cultivation in thress seeding seasons (June, July and August), in Pelotas, RS, 2016

\begin{tabular}{llllll}
\hline & MFGR $(\mathrm{g})$ & MFGP $(\mathrm{g})$ & MFCP $(\mathrm{g})$ & MFCR $(\mathrm{g})$ & MFF $(\mathrm{g})$ \\
\hline June & $4.17^{*}$ & 4.54 & $7.48 \mathrm{a}$ & 4.33 & $9.54 \mathrm{a}$ \\
July & 1.19 & 3.86 & $3.04 \mathrm{~b}$ & 1.58 & $2.89 \mathrm{~b}$ \\
August & 4.05 & 5.04 & $5.60 \mathrm{a}$ & 4.76 & $6.71 \mathrm{ab}$ \\
Average & $3.14^{\text {ns }}$ & $4.48^{\text {ns }}$ & 5.37 & $3.56^{\text {ns }}$ & 6.38 \\
CV $(\%)$ & 90.62 & 41.15 & 33.71 & 89.58 & 62.44 \\
\hline
\end{tabular}

Note. *Average followed by same letter in the column, do not differ statistically among themselves by the test of Tukey $(\mathrm{p}<0.05) .{ }^{\mathrm{ns}}$ Non significant by the test F.

Regarding variables related to dry matter mass (Table 6), the month of June has presented a significantly higher value as for dry mass of stem from the main. As for stem diameter from basal and average area (Table 7) no statistical difference occured, but in relation to apical region it is possible to verify that the month of June has made a difference, presenting a higher value $(0.52 \mathrm{~cm})$. 
Table 6. Average dry mass values (g) of ramification glomeruli (MSGR), dry mass of glomeruli from the main (MSGP), dry mass of stem from the main (MSCP), dry mass of ramification stem (MSCR), and dry mass of leaves (MSF), from quinoa cultivation, in three seeding seasons (June, July and August), in Pelotas, RS, 2016

\begin{tabular}{llllll}
\hline & MSGR $(\mathrm{g})$ & MSGP $(\mathrm{g})$ & MSCP $(\mathrm{g})$ & MSCR $(\mathrm{g})$ & MSF $(\mathrm{g})$ \\
\hline June & $0.88^{*}$ & 1.24 & $3.04 \mathrm{a}$ & 0.72 & $1.53 \mathrm{a}$ \\
July & 0.43 & 1.19 & $1.08 \mathrm{~b}$ & 0.52 & $0.46 \mathrm{~b}$ \\
August & 0.95 & 1.39 & $1.65 \mathrm{~b}$ & 1.05 & $1.04 \mathrm{ab}$ \\
Average & $0.75^{\text {ns }}$ & $1.27^{\text {ns }}$ & 1.92 & $0.76^{\text {ns }}$ & 1.01 \\
CV $(\%)$ & 90.27 & 45.08 & 44.03 & 85.9 & 59.61 \\
\hline
\end{tabular}

Note. *Average followed by same letter in the column, do not differ statistically among themselves by the test of Tukey $(\mathrm{p}<0.05) .{ }^{\text {ns }}$ Non significant by the test F.

Table 7. Diameter of stem-basal (DBC), diameter of stem-mediated (DCM), diameter of stem-apex (DCA), height of plant (AP), and panicle Length (CP) in centimeters produced during three seeding seasons (June, July and August). Pelotas, RS, 2016

\begin{tabular}{llllll}
\hline & DCB $(\mathrm{cm})$ & DCM $(\mathrm{cm})$ & DCA $(\mathrm{cm})$ & AP $(\mathrm{cm})$ & CP $(\mathrm{cm})$ \\
\hline June & 0.45 & 0.48 & $0.52 \mathrm{a}$ & $67.82 \mathrm{a}$ & $11.6 \mathrm{~b}$ \\
July & 0.47 & 0.37 & $0.25 \mathrm{~b}$ & $49.14 \mathrm{~b}$ & $13.2 \mathrm{~b}$ \\
August & 0.52 & 0.43 & $0.33 \mathrm{~b}$ & $59.73 \mathrm{ab}$ & $18.4 \mathrm{a}$ \\
Average & $0.48^{\mathrm{ns}}$ & $0.43^{\mathrm{ns}}$ & 0.37 & 58.89 & 14.4 \\
CV $(\%)$ & 35.44 & 25.84 & 36.89 & 17.11 & 24.43 \\
\hline
\end{tabular}

Note. *Average followed by same letter in the column, do not differ statistically among themselves by Tukey test ( $\mathrm{p}$ $<0.05) .{ }^{\text {ns }}$ Non significant by the test $F$.

Height of plants was notably inferior potential growth within the region (Table 3), since the highest value found in this experiment $(67.82 \mathrm{~cm}$ in the month of June) represent approximately $44 \%$ of the highest value verified during the month of December in the experiment before $(153.9 \mathrm{~cm})$. Months of July and August have presented a significantly lower value.

On the other hand, panicle lenght was negatively affected by the months of June and July, while August has shown higher lenght $(18.4 \mathrm{~cm})$. An issue that can present a reason for this data is the lowering concerning precipitation levels during that month, when compared to June and July (Figure 4).

In this experiment the evaluations concerning quality of the produced seeds haven't shown statistical interaction nor relevant differences in relation to location (main stem and ramifications), except on accelerated aging test (Table 8).

Table 8. Percentage of germination (G), test of cold (TF), accelerated aging (EA), and emergency (E) of seeds (main stem and ramification) produced during three seeding seasons (June, July and August). Pelotas, RS, 2016

\begin{tabular}{|c|c|c|c|c|c|}
\hline \multirow{2}{*}{ Variable } & \multirow{2}{*}{ Location on plant } & \multicolumn{3}{|c|}{ Season } & \multirow{2}{*}{$\mathrm{CV}(\%)$} \\
\hline & & June & July & August & \\
\hline \multirow[t]{3}{*}{$\mathrm{G}(\%)$} & Main & 89 & 96 & 97 & 5.11 \\
\hline & Ramification & 82 & 81 & 91 & 12.04 \\
\hline & Average & $86^{\mathrm{ns}}$ & $89^{\text {ns }}$ & $94^{\mathrm{ns}}$ & \\
\hline \multirow[t]{3}{*}{$\mathrm{TF}(\%)$} & Main & 89 & $95^{-1}$ & 93 & 3.87 \\
\hline & Ramification & 92 & 87 & 93 & 6.02 \\
\hline & Average & $91^{\mathrm{ns}}$ & $91^{\mathrm{ns}}$ & $93^{\mathrm{ns}}$ & \\
\hline \multirow[t]{3}{*}{ EA $(\%)$} & Main & $70 \mathrm{~b}$ & $98 \mathrm{a}$ & $93 \mathrm{~b}$ & 4.45 \\
\hline & Ramification & $77 \mathrm{~b}$ & $87 \mathrm{a}$ & $94 \mathrm{a}$ & 4.24 \\
\hline & Average & 74 & 93 & 94 & \\
\hline \multirow[t]{3}{*}{$\mathrm{E}(\%)$} & Main & 95 & 90 & $95^{-}$ & 10.1 \\
\hline & Ramification & 98 & 90 & 90 & 9.36 \\
\hline & Average & $97^{\mathrm{ns}}$ & $90^{\mathrm{ns}}$ & $93^{\mathrm{ns}}$ & \\
\hline
\end{tabular}

Note. *Average followed by same letter in the column, do not differ statistically among themselves by Tukey test ( $\mathrm{p}$ $<0.05)$. ${ }^{\text {ns }}$ Non significant by the test F. 
Like the hotter months, seeds produced during colder months (June, July and August) have presented themselves as viable and containing satisfactory germination values (between 81 and 97\%).

Accelerated aging test has shown that both of the plant's locations (main stem and ramifications) have presented higher strength during the month of July ( 87 and 98\%).

\section{Conclusions}

According to viability of quinoa's seeds (Chenopodium quinoa Willd.) produced in the Southern region of Brazil one may claim that there is a production potential within the region.

Quality of the seeds is assured when produced by the months of July, August and November, emphasizing that quality of the seeds of the main stem is also superior.

\section{Acknowledgements}

This work was conducted during a scholarship supported by the International Cooperation Program CAPES/COFECUB at the Federal University of Pelotas. Financed by CAPES - Brazilian Federal Agency and EMBRAPA, for Support and Evaluation of Graduate Education within the Ministry of Education of Brazil.

\section{References}

Borges, C. T. (2017). Desenvolvimento de metodologias para avaliação da qualidade fisiológica e conservação de sementes de quinoa (Chenopodium quinoa Willd.) (81f, Tese (Doutorado), Faculdade de Agronomia Eliseu Maciel, Universidade Federal de Pelotas, Pelotas, Brazil).

Carbone-Risi, J. J. M. (1986). Adaptation of the Andean grain crop quinoa for cultivation in Britain (123f, Tese (Doutorado), University of Cambridge, Cambridge).

Cardoso, C. O., Faria, R. T., \& Folegatti, M. V. (2004). Simulação do rendimento e riscos climáticos para o milho safrinha em Londrina, PR, utilizando o modelo CERES-Maize. Engenharia Agrícola, 24, 291-300. https://doi.org/10.1590/S0100-69162004000100005

Carrasco, P. G. (2003). Produção de mudas de espécies florestais de restinga, com base em estudos florísticos e fitossociológicos, visando a recuperação de áreas degradadas em Ilha Comprida-SP (187 f, Tese (Doutorado em Ciências Biológicas), Curso de Pós-Graduação em Ciências Biológicas, Universidade Estadual Paulista, Rio Claro).

FAO (Food and Agriculture Organization of the United Nations). (2017). Retrieved from http://www.fao.org/ faostat/en/\#data/QC

Hunziker, A. T. (1943). Los especies alimenticias de Amaranthus y Chenopodium cultivadas por los Indios de America. Revista Argentina de Agronomia, 30, 297-353.

León, A. E., \& Rossel, C. M. (2007). De tales harinas, tales panes: Granas, harinas y productos de panificación em Iberoamérica (p. 478). Córdoba: Hugo Baíez Editos.

Madl, T., Sterk, H., \& Mittelbach, M. (2006). Tandem Mass Spectrometric Analysis of a Complex Triterpene Saponin Mixture of Chenopodium quinoa. Journal of the American Society for Mass Spectrometry, 17, 795-806. https://doi.org/10.1016/j.jasms.2006.02.013

Marcos Filho, J. (2015). Fisiologia de sementes de plantas cultivadas (p. 659). Londrina: ABRATES.

Nakagawa, J. (1994). Testes de vigor baseados no crescimento de plântulas. In R. D. Vieira, \& N. M. de Carvalho (Eds.), Testes de vigor em sementes (p. 164). Jaboticabal: FUNEP.

Peixoto, C. P., Câmara, G. M. S., Martin, M. C., Marchiori, L. F. S., Pelúzio, J. M., Fidelis, R. R., ... Menegello, G. E. (2012). Sementes: Fundamentos científicos e tecnológicos (2nd ed., p. 574). Brasília: Ed. Universitária/UFPel.

Rocha, J. E. S. (2008). Seleção de genótipos de quinoa com características agronômicas e estabilidade de rendimento no Planalto Central (115 f, Dissertação (Mestrado em Agronomia), Universidade de Brasília, Brasília).

Rojas, W., \& Pinto, M. (2013). La diversidad genética de quinua de Bolivia. Congreso Científico de la Quinua. Ministerio de Desarrollo Rural y Tierras (Bolivia) Instituto Interamericano de Cooperación para la AgriculturaInstituto Nacional de Innovación Agropecuaria y Forestal.

Soares de Vasconcelos, F., E., G. B., M., \& Silvério, L. (2012). Desenvolvimento e produtividade de quinoa semeada em diferentes datas no período safrinha. Revista Ciência Agronômica, 43(3). 
Spehar, C. R. (2006). Adaptação da quinoa (Chenopodium quinoa Willd.) para incrementar a diversidade agrícola e alimentar no Brasil. Cadernos de Ciência \& Tecnologia, 23(1), 41-62.

Spehar, C. R., Santos, R. L. B., \& Veloso, R. F. (2007). Quinoa: alternativa para a diversificação agrícola e alimentar. Embrapa Cerrados, 1.

Streck, E. V., Kämpf, N., Dalmolin, R. S., Klamt, E., Nascimento, P. C., Schneider, P., ... Pinto, L. F. S. (2008). Solos do Rio Grande do Sul (2nd ed., p. 222). Porto Alegre: Emater/RS.

Verzani, J. (2008). Getting Started with RStudio, An Integrated Development Environment for R O'Reilly Media.

Walters, H., Carpenter-Boggs, L., Desta, K., Yan, L., Matanguihan, J., \& Murphy, K. (2016). Effect of irrigation, intercrop, and cultivar on agronomic and nutritional characteristics of quinoa. Agroecology and Sustainable Food Systems, 40(8), 783-803. https://doi.org/10.1080/21683565.2016.1177805

Wrege, M. S. W., Steinmtez, S., Junior, C. R., \& Almeida, I. R. (2011). Atlas climático da Região Sul do Brasil: Estados do Paraná, Santa Catarina e Rio Grande do Sul (p. 211). Pelotas: Embrapa Clima Temperado; Colombo: Embrapa Florestas.

\section{Copyrights}

Copyright for this article is retained by the author(s), with first publication rights granted to the journal.

This is an open-access article distributed under the terms and conditions of the Creative Commons Attribution license (http://creativecommons.org/licenses/by/4.0/). 